A Valuable Modification of the A postoli Treatment of Fibroid Tumors, G. Betton Massey, Philadelphia, Pa.

Sigmoid Surgery from the Intra.Pelvic or Intra-Abdominal Standpoint, J. G. Carpenter, Standford, Ky.

A Plea for the More Correct Application of the Emmet Method in Plastic Surgery, W. D. Haggard, Jr., Nashville, Tenn.

Section on Stomatology.-Dr, G. V. I. Brown, Milwaukee, Wis., Chairman; Dr. Eugene S. Talbot, Chicago Ill., Secretary. The following papers will be presented at the next meeting:

Chairman's Address, by G. V. I. Brown, Milwaukee, Wis.

Methods of Teaching Materia Medica, with Special Reference to the Needs of Dental Students, by W. B. Hill, Milwaukee, Wis.

A Method of Handling A lveolar Pyorrhea, by G. T. Carpenter, Chicago, Ill.

Only a Baby Tooth, by W. H. Hall, Denver, Colo.

The Management of Pulpless Teeth, by J.'Taft, Cincinnati, Ohio.

Epulides, by W. Knight, Cincinnati, Ohio.

Dental Septicemia of the Antrum, by V. A. Latham, Chicago. Some Facial Deformities and their Prevention, by A. E. Baldwin, Chicago, Ill.

Jaw Movements in Relation to Tooth Forms, by A. H. Thompson, Topeka, Kan.

Irregularities of the Dental Arch, by Eugene S. Talbot, Chicago, Ill.

The Resistance of the Mucous Membranes to Bacterial Infec tion, by V. A. Gudex, Milwaukee, Wis.

The Morbid Susceptibility of Dental Structures is Greater that that of Other Tissues, by A. H. Sawins, Denver, Colo.

Have We Progressed? by J. M. Porter, Denver, Colo.

\section{SOCIETY NEWS.}

Illinois State Medical Society.-For the forty-eighth annual meeting at Galesburg, May 17, 18 and 19, 1898, a rate of one fare and one third on the certificate plan (\$6.50 for the round trip from Chicago) is announced.

Association of Military Surgeons of the United States.-On account of the occupation of the members in connection with the war with Spain, it is announced that the eighth annual meeting, which was to have taken place June 1, 2 and 3 next, is postponed to a date to be fixed hereafter by the Executive Committee. James E. PIlcher, Capt. Med. Dept. U. S. Army, Secretary ; J. D. GriffTh, Lieut.-Col. and Med. Dir., N. G. Mo., President, Kansas City, Mo.

Association of American Medical Colleges.--The annual meeting of this association will be held at the Brown Palace Hotel, Denver, Colo., Monday, June 6, 1898, beginning at 10 o'clock in the morning. The Judicial Council will meet at the same place at $9: 30$ A. M. Each college, member of the association, is entitled to one representative and to one vote in all proceedings. The dean of the college is the official representative. When any other person acts in that capacity, he or she should bear an official appointment from the proper officers of the college. At a meeting of representatives of members of the association in Chicago, the following amendments to the Constitution were proposed :

Article III, Section 5 to read after "each course of at least six months duration," and each course of not less than 800 recitation hours, clinical and laboratory hours counting as half hours.

Article III, Section 7. A college not giving the whole four courses of the medical curriculum but otherwise eligible to membershin may be admitted to membership the same as if it completed the curriculum and graduated students.

The members of the boards of examiners of the several States and all medical teachers are invited to the morning session and to listen to the president's address in the afternoon. Bayard Holmes, 104 E. Fortieth St., Chicago, Secretary.

The American Gastro-Enterological Association.-At the annual session of the American Gastro-Enterological Association held at Washington, D. C., May 3, 1898, the following officers were elected: President, D. D. Stewart, Philadelphia ; first vicepresident, Max Einhorn, New York; second vice-president, John C. Hemmeter, Baltimore; secretary and treasurer, Charles D. Aaron, Detroit. Council : Henry L. Elsner, Syracuse; A. P. Buchman, Fort Wayne ; Frank P. Murdock, Pittsburg. The following papers were read :

A Case of Atrophy of the Stomach, with Exhibition of Specimen, by Julius Friedenwald, Baltimore, Md.

$\alpha$, A case of Acute Pancreatitis ; $b$, Carcinoma of the Cardia, by Morris Manges. New York.

Nervous Dyspepsia, with Report of Cases, by Frank $\mathrm{H}$. Murdock, Pittsburg, Pa.

$a$, The Effect of Auto-intoxication on the Liver and Kidneys; $b$, Exhibition of New Instruments for Intubating the Duodenum and Outlining the Greater Curvature and Colon, by John C. Hemmeter, Baltimore, Md.

Precision of Terms in Diseases of the Stomach, by Chas. D. Aaron, Detroit, Mich.

Ohio State Medical Society.-Resolutions passed. Columbus, Оhio, May 5, 1898.

To the Editor:-The enclosed report with its recommendations, was adopted today by the Ohio State Medical Society. The immediate publication of it will be a favor, as it will be presented for action at the Denver meeting of the Americas Medical Association. Yours truly,

Jno. A. Thompson, Secy.

To the President and Members of the Ohio State Medical Society.

Gentlemen:-Your committee on National Legislation appointed in response to the overture of the New York State Medical Society has awaited the call of the committee of that society for a meeting in Washington to perfect a National organization, but so far no call has been received. Copies of the resolutions of this society anent the Antivivisection Bill of Senator Gallinger, still pending, were sent by your chairman to Dr. Busey, chairman of the District Committee of the District of Columbia, and likewise to Senators Foraker and Hanna. Your committee received a reply from Senator Foraker and a promise to give your request a favorable consideration, but so far received no reply from Senator Hanna. The District Committee, however, caused your resolutions to be printed and placed in the hands of every member of the Senate. Apparently, if we may judge from the circular letter sent out recently by Dr. Howard Kelly of Baltimore, Senator Gallinger is still obstinate in his determination to override the all but unanimous sentiment of the medical profession, and to push the enactment of his mischievous measure into law. But up to this time, owing in no small degree to the efforts of this society, he has not yet succeeded in bringing it to a vote. But the antivivisectionists are persistent; they have ample means and time at their disposal; they have able and influential advocates resident in Washington, and the medical profession must also have its men on the ground, acting with full authority delegated to them in order to counteract the efforts of the so-called humane organizations to hamper and hopelessly cripple biologic and physiologic investigation in the Government laboratories, and in the medical schools of the District of Columbia.

It seemed to your committee last year that the New York plan provided for too large a body, a body which from its very size would prove too unwieldly for prompt and effective work, but the need of a body which shall authoritatively represent the convictions of the organized medical profession upon those matters of legislation, regarding which the medical profession alone has the training requisite to speak with proper authority, become increasingly evident, and your committee beg leave to submit the following plan of organization for the consideration of this society:

1. That the American Medical Association be requested to appoint a standing committee of three on National legislation, one member to be a resident of Washington, one of Baltimore and one of Philadelphia. A committee so located could be called together at Washington on short notice and appear before the committees of Congress at any time.

2. That each State society of legally qualified practitioners of medicine be requested to appoint a committee of one on National legislation, such committee to keep himself in com. munication with the senators and representatives from his own State, so that they may be always kept in touch with the med. ical profession concerning matiers of sanitary and medical legislation.

3. That a joint meeting of the committee of the AMERICAN MEDiCal A ssociation and the committeemen of the several 
State societies be held in Washington subject to the call of the Committee of the Amerrcar Medical Association. The purpose of that meeting would be to give opportunity for each State committeeman to personally interview the Representatives and Senators from his own State, and for the committee as a whole or by subcommittees to appear before the various congressional committees to set before them authoritatively the sentiments of the medical profession regarding pending legislation, and to urge the passage of measures upon which the medical profession of the nation have already agreed, and to which they have already given support by formal action. Meeting thus on the ground and consulting together the members of such joint committee would moreover become better cognizant of matters upon which the medical profession ought to take action, and by embodying such matters in their annual reports to their respective societies the sentiment of the medical profession as a whole would become promptly and authoritatively declared. We should thus begin to act as a unit in matters of national legislation affecting the sanitary interests of the people as a whole.

4. That the necessary expenses of these committeemen be borne by their respective societies.

In conclusion, your committee would recommend the adoption of the following resolutions:

Resolved, That we again enter our earnest protest against Senate Bill No. 1063, entitled "A Bill for the Further Prevention of Cruelty to Animals in the District of Columbia," for the reason that existing laws amply provide for the prosecution and punishment of any real cruelty to animals which may be proven to occur within the District, and because the physicians and scientists of the District have not so conducted themselves in the past as to warrant the system of irresponsible espionage authorized by the bill, and further because the paramount interest of the sick and afflicted demands that the medical profession shall have liberty to investigate the nature and treatment of disease free from cumbersome and vexatious restrictions such as are provided in the measure in question.

Resolved, That we again urge upon Congress the necessity of thorough inspection by a medical officer of the United States of all immigrants and their baggage before they embark for this country, in order that the importation of contagious and infectious filth diseases may be more effectually prevented. Resolved, That the secretary of this Society send a copy of these resolutions to each Senator and Representative in Congress from Ohio, and of the second resolution to the Chairman of the Committee on Commerce and on Immigration of both House and Senate. Respectfully submitted,

$$
\left.\begin{array}{l}
\text { L. B. Tuckerman, } \\
\text { RuFus B. HaLL, } \\
\text { A. M. Bleile, }
\end{array}\right\} \text { Committeo. }
$$

\section{PUBLIC HEALTH.}

Non heredity of Tuberculosis.-G. Kuss concludes from exten- eive research that the immense majority of cases of infantile tuberculosis are acquired after birth by inhaling the germs. The conclusion follows that the children of tuberculous patients should be removed at once after birth from all danger of contagion and brought up in an environment entirely free from tuberculous products. - Thèse de Paris, 1898.

Lepers Before the Courts.-A number of lepers in a Russian leprosorium recently attacked and flogged the superintending physician and were summoned to answer at the bar of justice for their criminal assault. But the court and jail officials objected decidedly to their presence and appealed to the higher courts, which decided the unprecedented affair by canceling the summons and leaving the matter to the administration of the institution.-St. Petersburg Med. Woch., April 9.

Endemic Pneumonia.-The Deutsche Med. Woch. of April 7 contains an account of four cases of extremely malignant lobular pneumonia in a family. The necropsy of one of the three fatal cases disclosed a mixed infection with the streptococcus and bacillus proteus. A parrot in the house was also affected, but no bacteriologic connection between it and the other cases could be established.

Bubonic Plague in Hong Kong.-Advices by the steamer Colum bia from the Orient as reported from Tacoma, Wash., May 5 , bring the current history down to April 6 . In the week pre- vious to the latter date cases in Hong Kong had increased and the colonial government was busy with plans to prevent a spread. A correspondent of the Hong Kong press states that forty new cases were occurring daily. A medical inspection of Chinese coming from Macao and Canton, where smallpox was also prevalent, has been instituted.

Pharmaceutic Advertisements in Non-medical Journals are not allowed in Russia, according to the Progrès Méd. No specialty can be advertised except in the medical press. A recent decree in Germany places "secret medicines" under the same regulations as poisons. The name, price, composition and maker must be plainly indicated; no testimonials, etc., are allowed on the bottle or wrapper. The administration reserves the right to prohibit the sale of certain remedies and establish a maximum price. Similar regulations are already in force in Russia.

How Long Will Diphtheria Serum Retain its efficiency was dis. cussed by Aaser of Norway (vide Journal, page 1060), and his conclusions for that cold climate have been practically confirmed by Abba of Turin, who states that the shortest period is a year and a half. It is not affected by light nor temperature, and some specimens retained their efficiency three years, but as a general rule it can be injected with confidence under a year and a half, without regard to changes in its color or transparency.-Gazz. degli Osp., February.

\section{NECROLOGY.}

David W. Yandell, M.D., died at his residence in Louisville, Ky., May 2, at 10 o'clock, P.м. He was taken seriously ill about four years ago, "never having been out of the house since

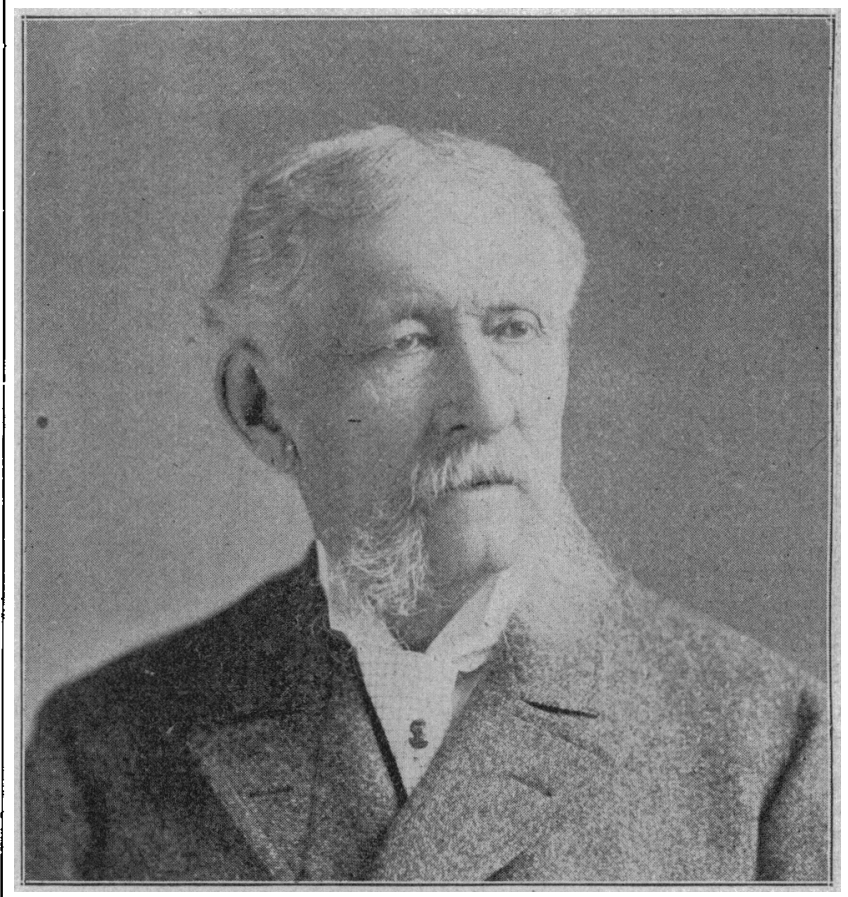

DAVID W. YANDELL, M.D.

that time, his end coming peacefully, surrounded by his family. Dr. Yandell was born in Tennessee, at Craggy Bluff, six miles from Murfreesboro, Sept. 12, 1826. This was near the spot afterward made memorable by one of the bloodiest battles of the civil war. His mother was a Miss Waddell and his father Dr. Lunsford P. Yandell, one of the leading physicians of Louisville and a professor in Transylvania University at Lexington, Ky. In 1831 Dr. L. P. Yandell moved to Lexington, where he remained until 1837, when he came to Louisville and 